\title{
PERANAN PERPUSTAKAAN SEKOLAH TERHADAP PENDIDIKAN AGAMA ISLAM
}

\author{
Siti Rozinah \\ Prodi Pendidikan Agama Islam, Fakultas Agama Islam, Universitas Nahdlatul Ulama \\ Indonesia \\ E-mail: sitirozinah@unusia.ac.id
}

\section{Article Information \\ Informasi Artikel \\ Naskah diterima: 10 Agustus 2020}

Naskah direvisi: 20 Agustus

Naskah disetujui:

September 2020

Naskah dipublish:

Oktober 2020

Kata Kunci Perpustkaan, Pendidikan Agama Islam, MTs Al Riyadl Cipanas

\begin{abstract}
Abstrak
Penelitian ini bertujuan untuk mengetahui sistem pengelolaan perpustakaan, dan mengetahui prilaku siswa dalam memanfaatkan layanan perpustakaan serta mengetahui peranan perpustakaan yang ada di MTs AL-Riyadl Cipanas terhadap Pendidikan Agama Islam. Metode yang digunakan dalam penelitian ini adalah metode deskriptif analisis dengan pendekatan kualitatif. Adapun Teknik pengumpulan data dalam dilakukan melalui observasi, wawancara, dan dokumentasi. Analisis data dilakukan dengan mengklarifikasikan data-data yang diperoleh kemudian dikumpulkan untuk dianalisis kemudian diambil kesimpulan. Penelitian menemukan bahwa sistem pengelolaan perpustakaan di MTs AL-Riyadl Cipanas adalah untuk pendataan buku menggunakan sistem komputerisasi sedangkan untuk peminjaman masih menggunakan manual. Faslitas yang ada mencakup ruang baca, buku peminjaman, kursi, meja dan ruang belajar sedangkan koleksi buku yang tersedia untk pendidikan agama Islam adalah 1000 koleksi. Prilaku siswa dalam memanfaatkan layanan perpustakaan di MTs AL-Riyadl Cipanas yaitu setiap harinya benar-benar memanfaatkan layanan perpustakaan yaitu membaca, meminjam dan belajar, dimana setiap ada waktu kosong siswa menyempatkan untuk pergi keperpustakaan. Perpustakaan di Mts Al-Riyadl Cipanas sangat berperan terhadap Pendidikan Agama Islam hal ini bisa dilihat dari banyaknya pengenjung yang selalu menambah pengetahuan, sebagai sarana, mempermudah mencari informasi, dan menambah wawasan siswa. Hal ini dapat menunjukan bahwa perpustakaan sangat berperan dalam meningkatkan pemahaman pendidikan agama islam siswa.
\end{abstract}




\section{PENDAHULUAN}

Ditengah-tengah lajunya pertumbuhan dan perkembangan Ilmu pengetahuan dan kemajuan teknologi seperti sekarang ini, sunber-sumber pengetahuan seperti buku, majalah, surat kabar, film dan sebagainya tumbuh dengan pesat. Kenyataan ini menuntut lembaga pendidikan untuk tetap hidup dan berkembang dalam arus globalisasi. Dengan kata lain lembaga pendidikan harus berorentasi ke depan, artinya mampu menyiapkan anak didiknya agar dapat beradaptasi bukan saja di masa sekarang akan tetapi juga masa yang akan datang.

Selain itu sebagaimana disebutkan dalam pembukaan UUD 1945 alinea ke empat, bahwa salah satu tujuan pembangunan nasional adalah mencerdaskan kehidupan bangsa.

Untuk merealisasikan tujuan tersebut, maka diperlukan adanya sarana dan prasarana pendidikan guna meningkatkan prestasi belajar mengajar, salah satu dari sarana dan prasarana pendidikan tersebut adalah merupakan tempat sumber informasi dan ilmu pengetahuan.

Pendidikan modern menghendaki agar para pelajar sebanyak mungkin melibatkan dalam proses belajar mengajar, sehingga apa yang diperoleh bukannya hanya diterima dari guru saja. Tetapi usaha mencari diri sendiri dari sumber-sumber lain sehingga pelajaran dari ilmu yang diperolehnya akan mudah dihayati hasilnya. Karena pentingnya perpustakaan dalam meningkatkan prestasi belajar siswa, maka mulailah digalangkan perpustakaan disemua jenis tingkatan sekolah. Tujuan didirikannya perpustakaan itu sendiri yang diantaranya agar timbul kecintaan terhadap membaca, memupuk kesadaran dan menanamkan kebiasaan membaca. ${ }^{1}$

Keberadaan perpustakaan sangat penting karena perpustakaan adalah merupakan “jantung dari pendidikan” yang menghidupkan sekolah dimana pendidikan itu dilangsungkan, keberadaan perpustakaan di lingkungan sekolah merupakan keharusan demi terciptanya proses pembelajaran yang baik dan dapat di pertanggung jawabkan secara akademik. Oleh karenanya secara operasional, pengelolahan perpustakaan harus benar-benar diposisikan secara tepat. ${ }^{2}$

\footnotetext{
${ }^{1}$ Hendayat Soetopo \& Westy Soemanto, Pengantar Operasional Administrasi Pendidikan, (Surabaya: Usaha Nasional, tt), h. 212

${ }^{2}$ Imas Maesaroh, Panduan Teknis Pengelolaan Perpustakaan, (Surabaya: 2001), h. 7
} 
Arti penting perpustakaan dalam dunia pendidikan karena adanya kebutuhan dari sekolah itu sendiri karena adanya kebutuhan dan perubahan yang terjadi dalam lembaga pendidikan. Masalah kebutuhan perpustakaan suatu sekolah adalah kehadirannya sangat di perlukan karena dapat menunjang kegiatan pendidikan, penelitian dan pengabdian kepada masyarakat. ${ }^{3}$

Dengan demikian dapat diambil kesimpulan bahwa peranan perpustakaan sekolah sangat penting artinya. Karena kehadiran perpustakaan sebagai pusat dan penyebar informasi sehingga membantu proses belajar mengajar dalam rangka mengkaji Ilmu Pengetahuan yang sedang berkembang.

Perpustakaan dengan unsur utama buku bisa mengantarkan siswa sebagai individu kedunia yang lebih luas, bahkan juga sebagai alat penghubung dalam menghubungkan peristiwa masa lalu, kini dan yang akan datang. Karena di dalamnya mengandung ide-ide manusia dari zaman ke zaman, pengetahuan serta budayanya, sehingga generasi muda tidak ketinggalan informasi.

Penyelenggaraan perpustakaan sekolah sebenarnya bukan hanya mengumpulkan buku-buku atau bahan pustaka, tetapi dengan adanya perpustakaan ini di harapkan dapat membantu murid dan guru menyelesaikan tugas-tugas dalam proses belajar mengajar pada tiap-tiap sekolah tersebut. Untuk itulah hendaknya perpustakaan sekolah disesuaikan dengan kurikulum, karena untuk menunjang proses belajarmengajar di sekolah y ang lebih penting lagi bahwa koleksi bahan perpustakaan sekolah harus memenuhi tuntunan kurikulum.

\section{METODOLOGI PENELITIAN}

Jenis penelitian yang di gunakan adalah jenis penelitian deskriptif. Penelitian deskriptif ini bertujuan untuk mendeskripsikan apa-apa yang saat ini berlaku. Sesuai dengan judul yang Peneliti angkat, maka metode penelitian yang kami gunakan adalah kualitatif. Menurut Bogdan Taylor mendefinisikan bahwa penelitian kualitatif adalah sebagai prosedur penelitian yang menghasilkan data deskriptif berupakata-kata, tulisan atau lisan dari orang-orang yang perilakunya diamati. 4

Penelitian Jenis ini termasuk dalam kategori penelitian kualitatif, sebab

\footnotetext{
${ }^{3}$ A. Zainuri, Minat Baca Mahasisiwa IAIN Sunan Ampel di Perpustakaan dalam Agama dan Kemasyarakatan, (Surabaya, 2001), h. 7

${ }^{4}$ Lexy J. Moleong, MetodologiPenelitian Kualitatif, (Bandung: Rosda Karya, 2002), h. 3
} 
pendekatan yang dilakukan adalah melalui pendekatan kualitatif deskriptif, maksudnya dalam penelitian kualitatif data yang dikumpulkan bukan berupa angka-angka, melainkan data tersebut berasal dari wawancara, catatan lapangan, dokumen pribadi. Seperti yang dikatakan oleh Bogdan dan Taylor mendefinisikan bahwa, metode kualitatif yaitu sebagai prosedur penelitian yang menghasilkan data deskriptif berupa kata-kata tertulis atau lisan dari orang-orang atau perilaku yang diamati penelitian ${ }^{5}$

Latar dalam penelitian ini difokuskan di MTs Al-Riyadl Cipanas. atas pertimbangan bahwa di lokasi inilah penulis menemukan adanya permasalahan dan tersedia sejumlah data dan sumber data yang diperlukan untuk kepentingan penelitian ini. Madrasah Tsanawiyah Al-Riyadl Cipanas terletak di daerah pegunungan yang memiliki suhu udara sejuk dan dikelilingi daerah perkebunan dan real estate, tepatnya di Kampung Loji Al-Riyadl RT. 03 RW. 18 Desa Cipanas Kecamatan Cipanas Kabupaten Cianjur Provinsi Jawa Barat.

Menurut Patton analisis data adalah proses mengatur urutan data, mengorganisasikannya ke dalam suatu pola, kategori, dan satuan uraian dasar. Ia membedakannya dengan penafsiran, yaitu memberikan arti yang signifikan terhadap analisis, menjelaskan pola uraian, dan mencari hubungan diantara dimensi-dimensi uraian. ${ }^{37}$

Analisa data yang digunakan dalam penelitian ini adalah deskriptif kualitatif, penelitian diskriptif bertujuan untuk mendiskripsikan apa-apa yang saat ini berlaku. Di dalamnya terdapat upaya mendiskripsikan, mencatat, analisis dan menginterpretasikan apa-apa yang sekarang ini terjadi atau ada. Jadi dalam penelitian ini peneliti hanyalah memaparkan situasi atau peristiwa. Dengan kata lain penelitian ini tidak mencari atau menjelaskan hubungan, tidak menguji hipotesis ataupun membuat prediksi, tetapi hanya berbentuk narasi yang bertujuan untuk mengumpulkan informasi aktual secara rinci yang menjelaskan tentang peranan perpustakaan sekolah terhadap Pendidikan Agama Islam.

Dalam penelitian kualitatif deskriptif, perlu menetapkan keabsahan data, pelaksanaan teknik pemeriksaan didasarkan atas kriteria tertentu. Menurut Moleong ada empat kriteria yang digunakan, yaitu derajat kepercayaan (credibility), keteralihan

${ }^{5}$ Lexy J. Moleong, (2002), h. 3

Vol. 6 No. 2. Okotober 2020

Halaman $179-190$ 
(transferability), kebergantungan (dependability), dan kepastian (confirmability) ${ }^{38}$. Analisis validasi data baik yang diperolah melalui observasi, dokumen maupun wawancara dengan kepala sekolah, guru, orang tua dan murid dan kemudian dilakukan penafsiran data sesuai dengan konteks permasalahan yang diteliti selanjutnya melakukan pengecekan keabsahan data dengan cara mengecek sumber data yang didapat dan metode perolehan data sehingga data benar-benar valid sebagai dasar dan bahan untuk memberikan makna data yang merupakan proses penentuan dalam memahami konteks penelitian yang sedang diteliti.

\section{KAJIAN TEORI}

Sebelum penulis mendefinisikan perpustakaan sekolah, sebaiknya terlebih dahulu penulis memaparkan arti atau definisi perpustakaan, sebab kata "sekolah" pada istilah "perpustakaan sekolah" merupakan kata yang menerangkan kata "perpustakaan". Memahami perpustakaan secara umum merupakan dasar memahami perpustakaan sekolah. Perpustakaan sekolah merupakan bagian dari perpustakaan secara umum. ${ }^{6}$

Perpustakaan sekolah tumbuh dan berkembang seiiring dengan perubahan kebijakan pendidikan Indonesia. Pertumbuhan secara mencolok tentang perpustakaan terjadi sejak tahun 1980-an. Pada waktu berbagi kebijakan tentang perpustakaan sekolah mulai muncul.

Salah satunya adalah surat keputusan Mentri Pendidikan dan Kebudayaan nomor 0103/0/1981 tentang pokok-pokok kebijakan pembinaan dan pengembangan perpustakaan di Indonesia. ${ }^{7}$ Perpustakaan bukan hal yang baru dalam kalangan masyarakat, karena dimana-mana telah diselenggarakan atau didirikan perpustakaan yang mana pemerintah pun telah mendukung dan menghimbau tentang hal tersebut.

Sebagai upaya mengembangkan potensi diri, yaitu minat baca. Masyarakat telah mengenal berbagai jenis perpustakaan sekolah, perpustakaan perguruan tinggi, kantor bahkan perpustakaan masjid. Bahkan sekarang ini sedang digalakkan tentang perpustakaan umum, baik yang ditingkat kabupaten sampai desa.

Walaupun bukan merupakan hal yang baru bagi masyarakat. Namun masih banyak yang memberikan defenisi yang salah tentang perpustakaan. Banyak orang

\footnotetext{
${ }^{6}$ Ibarahim Bafadol, Pengelolaan Perpustakaan Sekolah, (Jakarta: Bumi Aksara, Cetakan Keempat, 2005),h. 1

${ }^{7}$ Darmono, Perpustakaan Sekolah Pendekatan Aspek Manajeman dan Tata Kerja Perpustakaan, (Jakarta: Gra sindo, 2007), h. 12
}

Vol. 6 No. 2. Okotober $2020 \quad$ Halaman $179-190$ 
yang beranggapan bahwa perpustakaan adalah tumpukan buku-buku yang ada disuatu tempat tertentu dan disebut perpustakaan. Karena ciri perpustakaan adalah adanya bahan pustaka atau sering juga disebut koleksi pustaka. ${ }^{8}$

Di zaman ini orang saling bertukar fikiran dan informasi yang memakai produk tekhnologi antara lain seperti film,slide, mikrofilm dan lain sebagainya. Semua tersebut dapat diterima di perpustakaan sebagai koleksi bahan pustaka karena koleksi bahan pustaka sumber informasi ${ }^{9}$

Kata perpustakaan berasal dari kata dasar pustaka, yang mendapat imbuan(per) dan (an), sehingga berarti tempat atau kumpulan bahan pustaka. Sedang bahan pustaka adalah wadah informasi, dapat berupa buku dan non buku. Perpustakaan Sekolah Lanjutan Tingkat Pertama adalah bagian integral dari lembaga pendidikan tempat menyimpan koleksi bahan pustaka yang dikelola dan diatur secara sistematik untuk digunakan oleh murid dan guru sebagai sumber bahan informasi, dalam rangka menunjang program belajar dan mengajar di sekolah.10 Menurut Satuan Tugas Koordinasi Pembinaan Perpustakaan sekolah Departemen Pendidikan dan kebudayaan, yang dikutip oleh Ibrahim Bafadal, perpustakaan sekolah adalah koleksi perpustakaan yang diatur menurut sistem tertentu dalam suatu ruang merupakan kegiatan integral dalam proses belajar mengajar dan membantu mengembangkan minat bakat. Adjat Sakti dan kawan-kawan dan kamus kecil perpustakaan memberi definisi: "Perpustakaan adalah lembaga yang menghimpun pustaka dan menyediakan sarana bagi orang untuk memanfaatkan koleksi pustaka tersebut. ${ }^{11}$

Menurut Ibrahim Bafadal dalam bukunya yang berjudul "pengelolaan perpustakaan sekolah" Beliau mendefinisikan perpustakaan adalah suatu unit kerja dari suatu badan atau lembaga tertentu yang mengelola bahan-bahan pustaka, baik berupa buku-buku maupun bukan (non book material) yang diatur secara sistematis menurut aturan tertentu sehingga dapat digunakan sebagai sumber informasi oleh setiap pemakainya. ${ }^{12}$

Menyimak apa yang dikemukakan oleh Ibrahim Bafadal mengenai pengertian

\footnotetext{
${ }^{8}$ Ibarahim Bafadol, (2005), h. 2

${ }^{9}$ Stella Team StafPengajar SMP, Membina Perpustakaan Sekolah, (Yogyakarta: Kanisius, 1991), h. 17

10 Departemen Pendidikan dan Kebudayaan, Pedoman Penyelenggaraan Perpustakaan Sekolah Menengah Tingkat Pertama. (Ja karta: Balai Pustaka, 1998), h. 1

${ }^{11}$ Soetminah, Perpustakaan Kepustakawanan dan Pustakawan,(Yogyakarta: Kanisius, 1991), h. 3

${ }^{12}$ Ibarahim Bafadol, (1992), h. 3
} 
perpustakaan, maka dengan demikian perpustakaan sekolah merupakan unit kerja dari suatu sekolah yang menyelenggarakannya. Dalam perpustakaan sekolah adalah perpustakaan yang diselenggarakan dilembaga-lembaga sekolah yang menunjang program belajar mengajar dilembaga pendidikan formal tingkat sekolah baik sekolah dasar, sekolah menengah umum maupun sekolah lanjutan. ${ }^{13}$

Perpustakaan sekolah sebagai salah satu sarana pendidikan penunjang kegiatan belajar mengajar siswa yang memegang peranan yang sangat penting dalam memacu tercapainya tujuan pendidikan disekolah. Hakikat perpustakaan sekolah adalah pusat sumber belajar dan sumber informasi bagi pemakainya. Perpustakaan dapat pula diartikan sebagai tempat kumpulan buku-buku atau tempat buku dihimpun dan diorganisasikan sebagai media belajar siswa.

Darmono menerjemahkan perpustakaan sebagai salah satu organisasi sumber belajar yang menyimpan, mengelola, dan memberikan layanan dan bahan pustaka baik buku maupun non buku kepada masyarakat tertentu maupun masyarakat umum.

Lebih luas lagi pengertian perpustakaan sekolah adalah salah satu unit kerja yang berupa tempat untuk mengumpulkan, menyimpan, mengelola dan mengatur koleksi bahan pustaka secara sistematis untuk digunakan oleh pemakai sebagai sumber informasi sekaligus sebagai sarana belajar yang menyenangkan ${ }^{114}$

Berdasarkan pengertian di atas, maka dapat digaris bawahi bahwa perpustakaan adalah suatu lembaga yang bertugas untuk memberikan pelayanan mengenai berbagai macam informasi-informasi dan merupakan suatu tempat untuk mengumpulkan, menyimpan pengetahuan serta mengorganisasi dan mengajukan bahan pustaka (bacaan dan lain- lain) dengan suatu sistem tertentu untuk melayani kebutuhan pelayanannya.

\section{Faktor-faktor Pendidikan Agama Islam}

Dalam melaksanakan pendidikan agama, perlu diperhatikan adanya faktorfaktor pendidikan yang ikut menentukan keberhasilan pendidikan agama tersebut. Faktor-Faktor Pendidikan itu ada 5 macam, dimana faktor-faktor yang satu dengan yang lainnya mempunyai hubungan yang erat. Kelima faktor tersebut adalah Anak

\footnotetext{
${ }^{13}$ Supriya di, Pengantar Ilmu Perpustakaan, (Malang, 1994), h. 6

${ }^{14}$ Darmono, (2007), h.2-3
} 
didik, Pendidik, Tujuan Pendidikan, Alat-alat pendidikan, Millieu/lingkungan. ${ }^{15}$

Jadi dapat disimpulkan bahwa faktor-faktor Pendidikan Agama adalah sesuatu yang ikut menentuskan keberhasilan Pendidikan Agama yang memiliki beberapa bagian yang saling mendukung satu sama lainnya. Faktor-faktor Pendidikan Agama selanjutnya juga disebut dengan komponen-komponen pendidikan.

Menurut Toto Suharto dalam bukunya filsafat pendidikan Islam dengan memodifikasi konsepsi noeng muhadjir mengungkapkan secara filosofis komponenkomponen pokok pendidikan islam kedalam lima komponen, yaitu tujuan pendidikan, pendidik dan peserta didik, kurikulum pendidikan, metode pendidikan, dan konteks pendidikan. Kelima komponen ini adalah merupakan sebuah system, artinya kelima komponen itu merupakan satu kesatuan pendidikan yang masing-masing berdiri sendiri, tetapi berkaitan satu sama lainnya, sehingga terbentuk satu kebulatan yang utuh dalam mencapai tujuan yang diinginkan. ${ }^{16}$

Sedangkan alat pendidikan ialah segala sesuatu yang dipergunaan dalam usaha untuk mencapai tujuan dari pendidikan. Dengan demikian yang dimaksud dengan alat pendidikan agama ialah; Segala sesuatu yang dipakai dalam mencapai tujuan pendidikan agama. Dalam memilih alat/media pendidikan ada beberapa faktor yang harus diperhatikan. Seperti yang diajukan oleh Heinick yang berupa model perencanaan penggunaan media yang efektif yang dikenal dengan istilah (ASSURE) adalah singkatan dari: Analyze Learner Characteristik, State Objektive, Select, or Modify Media, Utilize, Require Learner Response and Evaluate. Perpustakaan Sekolah merupakan salah satu media pembelajaran yang dapat digunakan untuk mencapai tujuan pendidikan

\section{SISTEM PENGELOLAAN PERPUSTAKAAN DI MTS AL-RIYADL CIPANAS}

Dari hasil penelitian dapat diketahui bahwa sistem pengelolaan adminitrasi yang digunakan untuk pendataan buku menggunakan sistem komputerisasi (pendataan data secara otomasi) sedangkan penggunaan buku minjam pendataannya masih menggunakan manual. Perpustakaan MTs Al-RiyadlCipanas dalam pelayanannyajuga menggunakan sistem terbuka yaitu sistem layanan yang memungkinkan para pengguna secara langsung dapat memilih, menemukan dan mengambil sendiri bahan pustaka

\footnotetext{
${ }^{15}$ Zakiah Da radjat, (1993)h. 27

${ }^{16}$ Toto Suharto, Kurikulum Berbasis Kompetensi, (Bandung: Rosdakarya, 1987), h.77
} 
yang dikehendaki dari jajaran koleksi perpustakaan. ${ }^{17}$

Pelayanan dalam peminjaman buku dan pengembalian terdapat aturan yang digunakan yaitu bahwa peminjam tidak boleh meminjam buku lebih dari dua hal tersebut dikarenakan untk menjaga keamanan dan ketersediaan buku. Perpustakaan MTs Al-Riyadl membuat aturan bahwa setiap siswa tidak boleh lebih dari dua. ${ }^{18}$

Kelengkapan sebuah perpustakaan merupakan salah satu indikator pencarian data khusunya tentang buku PAI. Di perpustakaan MTs Al-Riyadl kelengkapan buku pendidikan agama sekita 1000 koleksi. Susasana perpustakaan adalah indikator lainnya untuk menjadikan perpustakaan lebih baik. Siswa MTs Al-Riyadl Cipanas setiap harinya benar-benar memanfaatkan layanan perpustakaan, dimana setiap ada waktu kosong siswa menyempatkan untuk pergi ke perpustakaan. Namun Siswa-siswa di MTs Al-Riyadl Cipanas sering tidak puas jika hanya bersumber kepada satu dua teks buku saja, hal ini dilakukan karena mereka (siswa-siswi) merasa perlu mengadakan perbandingan dengan materi yang ada di buku satu dengan buku yang lain, atau memperkaya materinya dengan membaca sumber-sumber referensi atau menambahnya dengan keterangan-keterangan yang mutakhir dari majalah, koran dan sebagainya yang semua bahan tersebut dapat diperoleh mereka dari perpustakaan.

Dengan adanya perpustakaan yang cukup baik dengan lengkapnya buku-buku yang ada dan relevannya dengan pelajaran membuat siswa yang memanfaatkan layanan perpustakaan sebagai sarana penunjang dan untuk menambah pengetahuan dan pengalaman responden sudah jelas dengan adanya perpustakaan sekolah pengetahuan siswa tentang Pendidikan Agama Islam semakin bertambah.

Meskipun pengetahuan siswa tentang Pendidikan Agama Islam lebih banyak dari kultur keluarga, tetapi dengan adanya perpustakaan sekolah siswa dapat membaca buku-buku yang ada dan pengetahuan siswa akan semakin bertambah. ${ }^{19}$

\section{PERANAN PERPUSTAKAAN SEKOLAH TERHADAP PENDIDIKAN AGAMA ISLAM}

Perpustakaan di MTs Al-Riyadl Cipanas bukan hanya sebagai tempat mencari referensi, baca buku dan lain-lain. Bahkan lebih dari itu yaitu tempat mereka (siswa)

\footnotetext{
${ }^{17}$ Wawa ncara dengan Yadi M. Nur,S.Ag, Kepa la Pepustakaan

${ }^{18}$ Wa wa ncara dengan Drs. H. Bai Sopandi, MM.Pd, Kepala Sekolah

${ }^{19}$ YadiM. Nur, S.Ag
} 
bermain dan santai. Hal ini bisa dilihat dengan adanya koleksi buku-buku cerita, majalah dan kliping-kliping yang ada diperpustakaan.

Perpustakaan sekolah sangat berperan sekali bagi lancarnya belajar mangajar, karena dengan adanya perpustakaan manusia bisa mengingat kehidupan sosial. Karena kemampuan seseorang sekarang kurang memadai dan pengetahuan manusia hampir seluruhnya telah tercatat dalam bentuk buku dan bahan-bahan pustaka lainnya, yang sampai batas tertentu terhimpun dalam koleksi sebuah perpustakaan sehingga dengan demikian segala apa yang telah dicapai manusia telah tercatat. Keberadaan perpustakaan disekolah-sekolah juga merupakan wujud kongkrit dari upaya pemerintah dalam meningkatkan aktifitas dan kualitas pembelajaran.

Penting arti dan peran perpustakaan pada umumnya masyarakat telah mengetahuinya, akan tetapi bagaimana halnya mengenai perpustakaan sekolah masih sedikit sekali yang memahami baik dalam hal pengorganisasiannya. Hal ini di sebabkan terutama selain belum adanya suatu perencanaan atau konsep kongkrit juga belum adanya keseragaman dalam hal penyelenggaraan perpustakaan sekolah. ${ }^{20}$

Jika di kaitkan dengan proses belajar mengajar di sekolah, perpustakaan sekolah mempunyai peran yang sangat berharga dalam upaya meningkatkan kualitas pendidikan dan pengajaran. Melalui penyediaan perpustakaan, siswa dapat berinteraksi dan terlibat langsung baik secara fisik maupun mental dalam proses belajar.

\section{Fungsi Perpustakaan Sekolah}

Fungsi edukatif, yaitu perpustakaan harus mampu membangkitkan minat baca siswa, mengembangkan daya ekspresi, mengembangkan kecakapan bebahasa, mengembangkan daya pikir yang rasional dan kritis serta mampu membimbing dan membina siswa dalam menggunakan bahasa pustaka dengan baik.

Fungsi informatif, yaitu perpustakaan haeus mampu menyediakan bahan-bahan yang beraneka ragam, bermutu dan up to date, yang di susun secara sistematis dan teratur. Fungsi administratif, yaitu perpustakaan harus mengerjakan pencatatan, penyelesaian dan pemprosesan bahan-bahan pustaka serta menyelenggarakan sirkulasi yang praktis, efektif dan efisien. Fungsi rekreatif, yaitu perpustakaan harus menyediakan buku-buku yang bersifat rekreatif (hiburan) yang bermutu

\footnotetext{
${ }^{20}$ Drs. H. Bai Sopandi, MM.Pd
} 


\section{Pelayanan Perpustakaan Sekolah}

Citra perpustakaan sekolah terutama ditentukan oleh pendapat pengunjung atau kesanggupan perpustakaan untuk mencapai tujuannya. Reputasi perpustakaan sekolah didasarkan atas jasa yang diberikannya, setiap perpustakaan sekolah harus memperhatikan benar hubungan dengan pengunjung. Sebuah perpustakaan sekolah yang dapat memberikan pelayanan dengan baik kepada pengunjung akan menarik minat pengunjung untuk mengunjungi perpustakaan tersebut. Sesuai dengan pendapat Rusiana Sjahrial dan Pamuntjak di atas bahwa melalui perpustakaan sekolah kepandaian membaca siswa dapat dimanfaatkan dan dikembangkan. Dengan arti lain bahwa pelayanan perpustakaan sekolah yang baik tentunya dapat meningkatkan minat membaca siswa. Pekerjaan pelayanan mencakaup empat kegiatan, yaitu: kegiatan pekerjaan peminjaman, kegiatan membantu pengunjung mencari informasi (referens), kegiatan mendidik pengunjung menggunakan alat perpustakaan dan bahan pustaka, dan kegiatan menyebarluaskan informasi. ${ }^{21}$

\section{PENUTUP}

Perpustakaan sekolah merupakan bagian integral dari program sekolah secara keseluruhan, di mana bersama-sama dengan komponen pendidikan lainnya turut menentukan keberhasilan proses pendidikan dan pengajaran. Melalui perpustakaan siswa dapat mendidik dirinya secara berkeseimbangan. Di harapkan dengan adanya perpustakaan sekolah siswa dan guru Pendidikan Agama Islam membangkitkan motivasi belajar dan menumbuhkan kegairahan di dalam membaca. Kegiatan belajar yang ditunjang oleh fasilitas perpustakaan yang memadai akan memberikan pengalaman ganda, yaitu dalam mencapai tujuan pengajaran tertentu dan kemampuan menggunakan perpustakaan sebagai pusat sumber belajar.

Oleh sebab itu perpustakaan pada suatu bangsa dan di lembaga- lembaga pendidikan adalah mutlak sangat dibutuhkan/memegang peranan penting. Bukan rahasia lagi, bahwa kadang-kadang di sekolah-sekolah, ruang kepala sekolah, ruang guru-guru dan karyawannya semua baik. Kemudian kita coba mengunjungi perpustakaannya, hampir-hampir tidak menimbulkan gairah memasukiya. Apabila kita masuk ke dalamnya, gelap karena tidak mempunyai lampu atau tidak cukup penerangan

\footnotetext{
${ }^{21}$ Rusiana Sjahrial dan Pamuntjak, Pedoman Penyelenggaraan Perpustakaan, (Jakarta: Djambatan, 2000), h.5
} 
di dalamnya, tidak cukup ventilasi sehingga udara lembap dan menyesakkan nafas. Oleh karena itu, perpustakaan haruslah digunakan dan dimanfaatkan sebanyakbanyaknya, semaksimal- maksimalnya. Buku-buku bukanlah hiasan. Bukan hiasan di kamar-kamar tertentu, di ruangan-ruangan yang berada di luar perpustakaan.

Dari pendapat diatas dapat melihat peranaan perpustakaan sekolah sangat besar tanpa perpustakaan sebagai penunjang utama maka pembelajaran sekolah tidak akan berjalan dengan sempurna. Bahkan dapat dikatakan maju mundurnya sekolah akan dipengaruhi oleh maju mundurnya peranan perpustakaan sekolah.

\section{DAFTAR PUSAKA}

Abdul Fattah Jalal, Tujuan Pendidikan Islam, Rosdakarya, Bandung, 2007 Amin, Akhlak dan Tasawuf, Nurjati Press, Cirebon, 2009

Darmono, Perpustakaan Sekolah Pendekatan Aspek Manajeman dan Tata Kerja Perpustakaan, Jakarta: Grasindo, 2007

Departemen Pendidikan dan Kebudayaan, Pedoman Penyelenggaraan Perpustakaan Sekolah Menengah Tingkat Pertama. Jakarta: Balai Pustaka, 1998

Ibarahim Bafadol, Pengelolaan Perpustakaan Sekolah, Jakarta: Bumi Aksara, Cetakan Keempat, 2005

Lasa HS, Membina Perpustakaan Madrasah \& sekolah Islam, Yogyakarta: Adi Cita Karya Nusa, 2002

Pawit M. Yusuf, M.S, Pedoman Penyelenggaraan Perpustakaan Sekolah,

Bandung: Kencana Prenada Media Group, 2007

Perpustakaan Nasional, Pedoman Penyelenggaraan Perpustakaan, Jakarta: Perpustakaan Nasional, 1998

Sulistyo Basuki, Periodesasi Perpustakaan Indonesia, Bandung: Remaja Rosda Karya, 1994

Supriyadi, Pengantar Ilmu Perpustakaan, Malang, 1994

Tadjab, dkk, Dasar-Dasar Kependidikan Islam, Surabaya: Karya Abditama, 1996

Teungku Muhammad Hasbi ash-Shiddieqy, Tafsir Al-Qur'anul Majid An-Nur, Jakarta:

PT. Pustaka Rizki Putra, Cetakan kedua, Edisi kedua, maret 2003

Toto Suharto, Kurikulum Berbasis Kompetensi, Rosdakarya, Bandung, 1987 Zakiah

Daradjat dkk, Ilmu Pendidikan Islam, Jakarta: Bumi Aksara, 1993 